International Journal of Research in Education and Sustainable Development | ISSN: 2782-7666

Vol. 1, Issue 1 (January, 2021) | www.ijaar.org

Journal DOI: 10.46654/IJRESD

Article DOI: 10.46654/IJRESD.117125

\title{
UNTOLD IMPACTS OF NIGERIA'S LAND BORDERS CLOSURE POLICY ON BORDER COMMUNITIES, ECONOMY, AND SECURITY IN WEST AFRICAN SUB-REGION
}

\author{
Dr. Temitope Francis Abiodun \\ Department for Peace, Security and Humanitarian Studies, \\ Faculty of Multidisciplinary Studies, \\ University of Ibadan, Nigeria. \\ E-mail: abiodun.temitope3@gmail.com \& tf.abiodun@ui.edu.ng
}

\begin{abstract}
In recent time, the Nigerian government shut its land borders with neighbouring states of: Benin Republic, Cameroon, Chad and Niger over what were observed to be; increase in smuggling activities, alleged security breaches, trafficking, incidence of illegal cross-border activities, undocumented migration, among others in the West African sub-region. However, the continual closure of these borders appeared to have affected the activities of border communities, regional and national economies. The study examines the reasons for shutting the borders; finds out the impacts of the closure on border communities, regional/national economies and security; finds out the reactions of border communities and neighbouring states; and interrogates the remedies to the problem. The study adopts a hegemonic stability theory to explain the phenomenon surrounding the closure while it employs quantitative and qualitative research methods. The paper in its findings therefore indicates that the state closed her land borders to forestall all illegal actions at borders involving: smuggling and human trafficking, illicit arms trade, undocumented migration among others. The study also reveals that the closure led to economic hardship for people in border communities, West African sub-region and the Nigerian state at large. The study therefore recommends that; there should be cross-fertilization of ideas on transnational economic, legal and security initiatives between the Nigeria and her neighbouring states to wage war against illicit activities at borders. The study however concludes that the border closure poses a major blow to pan-African moment having cut short all trade relations with other states; hoping that the policy would be very significant in protecting Nigeria's political, economic and security interests.
\end{abstract}

Keywords: Border security, Border communities, Hegemonic stability theory, Economy, Nigeria. 
Journal DOI: 10.46654/IJRESD

\section{Introduction}

Borders globally, are actually fundamental elements of human lives and at the same time elements of relations between individuals and society. From the time immemorial, ingredients of humanity have always been separated and also connected by a network of borders at all territorial levels (Kolossov, 2012). Therefore, the realization that borders characterize complex social and territorial phenomena has definitely had a profound impact on the study of borders. Trans-border commerce between Nigeria and her neighbouring states usually remains mutually beneficial. Nigerian traders import lots of cereals and grains, vegetables, tubers (yams, cassava, potatoes) and livestock from the countries; Niger, Benin and Chad to make up for the shortfalls in Nigeria. And manufactured household products and building materials are exported from Nigeria to these countries (Adeyinka, 2014). This trade exchange involved by the countries globally remains a central part of the economy. The infractions that go along with all these commercial exchanges are not expected to bring down the entire system, which the border closure seems to portend. It is on good note that millions of Nigerians have been living in peace for generations in most of the West African and other African countries, while some have been fully integrated into the host countries as well. There are about two million Nigerians living in Côte d'Ivoire, three million in Cameroon while the numbers in Benin Republic and Niger may be as high as $30 \%$ of the entire population (Agbota, 2020). However, more of Nigeria's interest is uphold of the ECOWAS Treaty on the free movement of people and goods in West Africa region.

However, days after being sworn in as president for second term in office, that is, 12th of June, 2019, President Muhammadu Buhari in his speech submitted that, in order to shrink security challenges through the nation's external borders, most especially smuggling of oil products out of the country, inflow of small arms, weapons and drugs into the country, and similarly protect the nation's local manufacturers, there was dire need to close down all Nigerian land borders (Agbota, 2020). This policy came into effect from August 20, 2019 when the Nigerian government unavoidably shut all land borders with its neighbouring countries of: Cameroon, Chad, Benin Republic, and Niger Republic over what was perceived to be as a result of the; increase in smuggling activities, alleged security breaches, trafficking, incidence of illegal crossborder activities, undocumented migration, and at the same time, abuse of international trade development procedures migration in West African sub-region (Basil, 2019).

The continual closure of the land borders for over a year now has, however, raised lots of concerns about the validity and essence of the Economic Community of West African States' Treaty which actually permits the free movement of people, goods and services across West African region. Since ECOWAS' formation by Nigeria and Togo through their respective Heads of State, General Yakubu Gowon and General Eyadema of Togo in 1975, it has remained a regional organization with several which include; the ECOWAS Parliament, ECOWAS Court, ECOWAS Passport, and Regional Force (known as ECOMOG) (ECOWAS Reports, 1975). All the same, usual quest for regional integration has always hibernated with numerous challenges. Therefore, violation of the Organization's treaty on movement of goods and people, giving room for the smuggling of firearms and drugs, human trafficking, trans-border insurgency among 
Journal DOI: 10.46654/IJRESD

several infractions have posed grave threats to the peace, stability and economies of member states (News Agency of Nigeria, 2015).

Border closure, however, remains a grim decision that is taken by states in astonishing situation, most especially when it is actually meant to protect a state's territorial integrity (Miller, 2012). But, border closure as a means of fighting smuggling and criminal activities has been a very worrisome challenge, most especially in the continent of Africa, where the existing porous borders in the continent are mostly peopled by communities of the same and various ethnic groups, who actually depend on, engage and survive on trans-border businesses and smuggling activities (Newman, 2011). Therefore, border closure for over a year by the Nigerian state has actually heightened state of unease or suffering as nearly all the border communities are worst hit with millions of residents losing their gainful jobs with while a very large percents of small and medium enterprises (SMEs) have been grounded and even relocated elsewhere (Oguntoye, 2020).

In the same vein, the continual closure may have led to serious economic hardship for people in border communities, in Nigeria, and West African sub-region respectively. It is also envisaged that any attempt on further or prolonged closure of these land borders by the Nigerian government could be taken to mean that the Nigerian state may have shown her displeasure at the complicity of her neighbouring states and other territories indulging in criminal activities (Oguntoye, 2020). At the same time, further the closure period elongation at this critical point in time may be deciphered to mean a total economic denial to the various affected nations, as same awful pattern could be reciprocated against Nigeria by other states (if they become aggressive) in the continent in the nearest future (Agbota, 2020).

The major objectives of the study, therefore, are to examine the reasons or factors that spurred the Nigerian government into shutting the borders; find out the impacts of the closure on border communities, regional/national economies and security; find out the reactions of border communities and neighbouring states; and finally interrogate the remedies to the problem. The research would definitely assist the Nigerian government, other African states, and stakeholders on performance improvements in the areas of border management and control towards improving and bettering the border communities' engagements, nation's economy, and sustenance of national security. It would also go a long way in assisting the neighbouring states to Nigeria on how to sustain their economies in the absence of Nigeria's borders' opening. In order to adequately achieve the stated objectives for the research, the paper is structured as follows: introduction; followed by methodology; theoretical framework; conceptual analysis; research findings and discussions on the impacts of borders closure to activities of border communities, economy, and security; reactions of border communities' residents and people from neighbouring states; limitations of the study; and lastly, conclusion and recommendations.

\section{Research Methodology}

The study employed the use of qualitative and quantitative research methods with significant reliability index. Data were gathered from primary sources, as copies of questionnaire were administered on respondents while a reasonable number of respondents were selected through purposive sampling technique for interview because of their expertise and knowledge on border 
Journal DOI: 10.46654/IJRESD

security and management. They respondents were workers, commercial riders and drivers, businessmen and women, forward clearing agents, bankers and residents in selected border communities in Nigeria and selected few of residents and security personnel from three (3) (Benin, Cameroon, and Chad) out of the four (4) neighbouring states of: Niger, Benin, Chad, and Cameroon. Other respondents were drawn from; the Nigeria Customs Service, National Boundaries Commission, members of the Manufacturers Association of Nigeria (MAN), and Nigeria Immigrations Service, and three Political Science and International Relations scholars from the Covenant University, Ota, Ogun State and University of Lagos, Nigeria respectively. The secondary data sources employed include: existing literature on border studies such as books, internet, journals, newspapers, magazines, conference papers, Nigerian Bureau of Statistics, Nigeria Immigrations and Customs Service reports, business reports from the Manufacturers Association of Nigeria (MAN), FAAC reports, UN, Thailand Rice Export Association (TREA), United Nations Conference on Trade and Development (UNCTAD), and ECOWAS publications, periodicals and other related documents. In the course of the study, the researcher made use of libraries of the Department of Peace, Security and Humanitarian Studies, University of Ibadan, Nigeria, to construct the impact index of the policy while a descriptive method was employed for the analysis.

\section{Theoretical Framework}

As argued by Hardi and Uszkai (2017), the position of borders has constantly changed over time, depending on the historical, political, geographical and other uniqueness of the given region. There were times when a given border was easily permeable and at other times it got more difficult to cross - therefore, the intensity of integration is also variable. Pursuant to the arguments stated above, hence the need to adopt the Hegemonic Stability Theory (HST) for the study. The hegemonic stability theory was espoused by: Stephen Krasner, Robert Gilpin, George Modelski, and Robert Keohane respectively. The essential proposition of this theory is that powerful states or nations deploy the influence and other resources at their disposal to compel weaker states or nations to behave or act in accordance to the dictates of the powerful or strong state (Hardi and Uszkai, 2017). This particular theoretical framework remains suitable to explain the decision of the Nigerian government in closing all its land borders towards achieving and strengthening its domestic economic, security and political interests in all sense.

However, hegemonic stability theorists believed that other countries will value order made at the outlay of some autonomy and benefits which the order has made possible to be justified; and ceding some ability to act unilaterally (Prabhakar, 2010). In this regard, the strongest state bears much of the responsibility for articulating and enforcing a specific order in exchange for gaining or realizing the type of order it actually desires at any given point in time. And at the same time, smaller or weaker nations will go along in sacrificing autonomy for the material benefits which order gives room to or allows (Prabhakar, 2010). Therefore, the hegemonic stability theory (HST) exists to maintain stability and order whereas the function of borders is to define the area to be used when calculating comparative advantages or benefits. In addition, trade and immigration policies actually depend on the nature of the hegemony of a state; and therefore, pursuant to this study, the hegemony of Nigeria in the West African sub-region, remains the strongest and most giant economy, largest population and the strongest military force. This 
Journal DOI: 10.46654/IJRESD

definitely gives Nigeria the main confidence to close all its land borders towards compelling a total obedience from her weaker neighbouring states that have alleged and solely blamed for illegal and undocumented migration, importation of contraband goods through illegal routes and harbouring of various criminals and terrorists in the region.

In the words of Minghi (1963), the border is not an ordinary geographical expression that shows where a nation ends and other begins but at globalization realm that is mostly characterized by treaties and agreements on trades, movement of goods and people, borders could be deployed as an instrument to wield enormous political and economic influence over weak neighbouring states depending on it politically and economically. This research work obviously also depicts that border restriction can be deployed to compel all other neighbouring states to implement economic measures and security strategies when the need arises. The decision of Nigeria to shut down its border has metamorphosed from internal affairs to West African economic, political, and diplomatic issues following the strategic influence of the country in the sub-region. That is the bane of the affected states' worries about the economic impacts of the borders closure on their economies (Minghi, 1963).

\section{Conceptual Analysis}

\section{Concept of Border}

The concept of state border dictates the understanding of, and indeed the very condition of prospect for, both local and international legal and political systems (Vaughan-Williams, 2009). Nationally, borders are significant to conventional notions of the limits of internal sovereignty and authority, as espoused in Max Weber's definition of the state as a human community that successfully claims the monopoly of the legitimate use of force within a given territory (Weber, 2012). Conventionally, borders are conceptualized to be international boundaries between nation states. Borders can be natural in form of; sea, mountains, rivers, among others but they are in any case always artificial, or objects of consensus and agreements, conquests and peace treaties (Ramuntsindela, 2014).

O`Dowd (2003) defines borders to be places of economic and political opportunities for nations as well as for a host of other interest groups, agencies, either legal or illegal. In the submissions of Newman and Paasi (1998), borders are made known to serve two fundamental purposes which include; protection from external and internal threats and territorial determination while Zartman (2010) agrees that borders run across land but through people. However on maps, borders appear as one- dimensional lines while on the ground they have several dimensions; and without mincing words, borderlands are boundaries in depth, space around a line, the place where state meets a society, and where no one ever feels at home (Simon, 1997). Also in the words of Caflisch (2006), the borders are broadly conceptualized as a way of identifying areas where state sovereignty usually exists, but Lee and North (2016) on the other way round, defines the concept of borders to symbolize a relatively static model of territorial demarcation which can be expressed physically, either through human-constructed border stones, walls, fences or through natural features like; as mountains ranges, rivers, and even trees. 
Journal DOI: 10.46654/IJRESD

The crucial function of geographic borders is to create and differentiate places. In other words, borders separate the social, political, economic, or cultural meanings of one geographic space from another (Diener and Hagen, 2012). Essentially, a border is an international line or a region encompassing both sides of a political boundary. Borders in other way round means artificially constructed, geographic lines that form the boundary of a state or nation. Borders are described to be integral components of human activity and organization. Borders are usually central element in contemporary international disputes relating to security, migration, trade, and natural resources, and they also factor prominently into local debates over land use and property rights (Diener and Hagen, 2012). Concept of borders has increasingly become complex human responses and social constructions in a system where the globalizing forces of on the spot communications, further travels and enhanced economic surge, confronting the basic human concerns for security and certainty.

In the same vein, Guo (2015) argues technically that, international borders in the world can be classified into three categories: natural, artificial and cultural. Natural borders are those that follow natural geographic features, such as rivers, mountain ranges, estuaries and the like. Examples include much of the border between the United States and Mexico which follows the Rio Grande and the border between France and Spain which follows the Pyrenees mountain range. Geometric borders that are also known to be a straight-line border, are those that are formed either by straight lines which are drawn on a map or nautical chart and by lines that follow the curves of latitude. Also, most of the international borders in the Middle East and North America are based on such geometry; while Cultural borders are the ones that usually follow or approximate the actual boundaries between the homelands of different ethnicities, language groups and other cultural communities. And several international borders in Europe usually follow such cultural divisions, even the border between Hungary and Romania (Guo, 2015).

\section{Concept of Border Communities}

The concept of border communities could only be understood when the actual meaning of a community is adequately deciphered. To full comprehend the concept, there is a need to first understand what a 'community' signifies. A community is defined to be a social unit, that is, a group of people living together with commonality such as: norms, religion, values, customs, and identity (Hawley, 2005). However, it is observed that communities share a sense of place situated in a given geographical location - it could be a country, village, town, or neighbourhood or in a virtual space through communication platforms. In the same vein, the durable relations that extend beyond direct genealogical ties also characterize a sense of community, important to their identity, practice, and roles in social institutions such as family, home, work, government, society or humanity at large (Hawley, 2005).

Therefore, border communities can now be conceptualized to be the towns, cities, and municipalities that are located in Nigeria and within a designated geographic service area but whose residents are typically receiving their primary or emergency care in adjacent geographic service or neighbouring countries due to service availability and proximity or distance (Adesina, 2019). In Nigeria, there are various border communities which include: Ilaro, Idiroko, Seme, Oke Odan, Ipokia, Owode, Mawun, Alari, Koko, Badagry, Ajilete, Ago, Ighonyedo and Ifo, Okerete, 
Journal DOI: 10.46654/IJRESD

Article DOI: 10.46654/IJRESD.117125

Banki, Maitagari, Imade Dura and Jibia among others. And superlatively, it is very normal for border communities to rely on trade, economic and commercial activities within and across borders to earn their means of living (Agbota, 2020).

\section{Research Findings and Discussion}

\section{Respondents' Information}

\begin{tabular}{|l|l|l|l|}
\hline \multicolumn{4}{|c|}{ Gender of the Respondents } \\
\hline Serial No. & Response & Frequency & Percentage \% \\
\hline 1. & Male & 203 & 51.26 \\
\hline 2. & Female & 193 & 48.73 \\
\hline & Total & 396 & $100 \%$ \\
\hline
\end{tabular}

\begin{tabular}{|l|l|l|l|}
\multicolumn{2}{|c}{ Age of the Respondents } \\
Serial No. & Response & Frequency & Percentage \% \\
\hline 1. & $18-30$ & 163 & 41.16 \\
\hline 2. & $31-45$ & 123 & 31.06 \\
\hline 3. & $46-55$ & 71 & 17.92 \\
\hline 4. & 56 and Above & 39 & 9.84 \\
\hline & Total & 396 & $100 \%$ \\
\hline
\end{tabular}

Marital Status of the Respondents

\begin{tabular}{|l|l|l|l|}
\hline Serial No. & Response & Frequency & Percentage \% \\
\hline 1. & Single & 191 & 48.23 \\
2. & Married & 81 & 20.45 \\
\hline 3. & Divorced & 52 & 13.13 \\
\hline 4. & Widow & 46 & 11.86 \\
\hline 5. & Widower & 25 & 6.31 \\
\hline & Total & 396 & $100 \%$ \\
\hline
\end{tabular}

\section{Educational Qualifications of the Selected Respondents}

\begin{tabular}{|l|l|l|l|} 
Serial No. & Response & Frequency & Percentage \% \\
\hline 1. & SSCE & 78 & 19.70 \\
\hline 2. & OND/Equivalent & 98 & 24.75 \\
\hline 3. & BSc/HND & 199 & 50.25 \\
\hline 4. & Masters/PhD & 21 & 5.30 \\
\hline & Total & 396 & $100 \%$ \\
\hline
\end{tabular}

\section{Employment Status of the Respondents}

\begin{tabular}{|l|l|l|l|}
\hline Serial No. & Response & Frequency & Percentage \% \\
1. & Employed & 100 & 25.25 \\
\hline 2. & Unemployed & 220 & 55.55 \\
\hline 3. & Self Employed & 76 & 19.19 \\
\hline & Total & 396 & $100 \%$ \\
\hline
\end{tabular}


Journal DOI: 10.46654/IJRESD

\begin{tabular}{|l|l|l|l|}
\hline \hline \multicolumn{5}{l}{ Locations of the Respondents } \\
\hline Serial No. & Response & Frequency & Percentage \% \\
\hline 1. & Cameroon & 16 & 4.1 \\
\hline 2. & Chad & 26 & 6.57 \\
\hline 3. & Benin Republic & 46 & 11.61 \\
\hline 4. & Seme Community & 66 & 16.6 \\
\hline 5. & Idiroko Community & 90 & 22.73 \\
\hline 6. & Badagry Community & 86 & 21.72 \\
\hline 7. & Banki Community & 66 & 16.67 \\
& Total & 396 & $100 \%$ \\
\hline
\end{tabular}

Source: Field Research Survey, 2019.

\section{RESEARCH QUESTIONS}

Question 1: What are the reasons or factors that pushed the Nigerian government into closing its land borders in 2019?

\begin{tabular}{|l|l|l|l|} 
Serial No. & Response & Frequency & Percentage \% \\
\hline 1. & Yes & 296 & 74.17 \\
\hline 2. & No & 100 & 25.13 \\
\hline & Total & 396 & $100 \%$ \\
\hline
\end{tabular}

Source: Field Research Survey, 2019.

Respondents' responses on the reasons or factors that spurred the Nigerian government into closing the borders

The responses from the research indicate that the Nigerian government shut down the nation's land borders in 2019 owing to the key factors or reasons giving way to illegal cross-border engagements and undocumented movements and as well obstacles to border security and management in Africa among others as follows:

\section{Increased rate of undocumented migration}

There is growing criminal engagements of migrants despite tightening of borders to block criminals and terrorists. The level of population growth in a state may have put uncontrollable pressure on available resources therein, thereby resulting to the illegal migration of people from that state to another country or destination to seek greener pastures. Most of the states in African remain densely populated and as a result of this, people migrate to other states without having documents for documentation at borders. These set of people enter through various illegal routes. They migrate illegally without proper documentations and also take illegal and unauthorized routes to different locations they so wish. However, it is regrettable that illegal immigrants find it easy to stay in Nigeria for years and work in all sectors of the economy without being detected by security agencies. About 120 illegal immigrants were arrested and paraded by Nigerian Immigrations Service, Kwara State Command, for not having valid documents as a 21-year-old Musa Isa, from Niger Republic, who had lived in the Nigeria for over ten years, stated that his 
Journal DOI: 10.46654/IJRESD

major mission to Kwara State, Nigeria was to work and get money to feed himself and later marry (Field Research Survey 2019).

\section{Incessant conflicts in the country}

People migrate as refugees due to prolonged conflicts and insecurity in their various places of origin while others migrate to unite with their families that have been separated by colonialism into different nation states. Therefore, the increasing spate of communal clashes, conflicts and insecurity in Nigeria for decades now are believed to have escalated from illegal and undocumented movements into Nigerian state (Field Research Survey 2019).

\section{Illegal cross-border trades taking place at borders}

There are cases of illegal cross-border trading activities taking place along Nigeria's borders with other African states like: Niger Republic, Benin Republic, Republic of Chad, and Cameroon which encourage influx dangerous arms and weapons, illegal movements or undocumented migration into the country. Most of these trading activities occur inform of: dealings in proliferation of arms and weapons, vehicles smuggling, used cloths and other consumable items (Field Research Survey 2019).

Abuse and absence of international trade development procedures, integration and cooperation There is abuse with absence of international trade development procedures, integration and cooperation among the states in the continent. This lack of integration remains order of the day at all levels: both continental and regional respectively. At the same time on local level, most border management bodies put in place usually fail to carry the border communities along. In the same vein, many more of security deployments are often carried out without including local interests or partnering with locals in the country despite their comprehensive knowledge of the border terrain. And there is total abuse of international trade facilitation procedures by the neighbouring states, hence the need for Nigeria to shut down all her land borders to checkmate this trend (Field Research Survey 2019).

The security situation within the state and at the Nigerian borders became seriously worsened Undocumented migration has created many border problems which have in turn affected the security situation in many African states, most especially in Nigeria. It is no more an exaggeration to state that Nigeria has faced the most worrisome security threat in history after the Nigerian civil war, and all is attributed to the Boko Haram insurgency. Therefore many lives have been lost as a result of this growing ugly situation. It is obvious that proper migration documentation with border control has not been taken into consideration for long, thereby giving room for all sorts of security threats in the country. The study reveals that the entire West African sub-region has been inundated with small arms and ammunitions which have in turn increased serious crimes in the region (Field Research Survey 2019).

\section{Threats to Nigeria's democracy and elections}

It is astonishing that the civic responsibility of voting during elections that is strictly and exclusively meant for Nigerian citizens is other way round being carried out by illegal immigrants in Nigeria. This evidenced in a report by Odunsi (2014) that the Nigerian Immigrations Service (NIS) through intelligence report, apprehended and repatriated 431 
Journal DOI: 10.46654/IJRESD

undocumented immigrants in Jigawa State between the months of January and November 2014while a large number of permanent Nigerian voter cards were seized from nationals of Niger Republic that entered into Nigeria illegally. Also and amongst those arrested, 90\% of them were from Niger Republic while others were from Cameroun, Chad and Mali (Field Research Survey 2019).

Illicit smuggling or influx of contraband goods, small arms and weapons into the country

Research and statistics indicate that there exist numerous migrants in Nigeria who entered the country since the beginning of the 20th century while the undocumented migrants in north eastern part of Nigeria have invented several traditions of smuggling prohibited goods in and out of the region. That is the reason Musa (2013) argues that these deadly migrants have created many techniques of ensuring easy border-crossing, mainly by clandestine passageways, since weapons are small, light and collapsible; backs of donkeys, camels and cows are used arms carriers into Nigeria. Similarly, arms are hidden in grains usually conveyed in large number via trucks, trailers, lorries and old model pickup vans and jeeps that are unsuspected by security operatives (Field Survey 2019).

Porosity of Nigerian land borders remain poses threats to national security and economy

The nature of Nigerian borders that remain porous either land or sea or the Niger Delta area has made possible the trade of oil for weapons as a major business to thrive and become fiercely guided by the beneficiaries (Musa 2013). The porous nature of our borders has also given an edge to proliferation of dangerous weapons and also given room to the dreaded Boko Haram terrorists that have claimed thousands of lives and property in Nigeria to freely operate. These various porous walk paths are very difficult to be adequately manned by the law enforcement agents. It is obvious that that the irresistible fight against harmful goods through land, waterways or high seas in the creeks into the country would definitely affect the successful fight against terrorism in the state. All these factors or reasons put together made the Nigerian government to close all her land borders (Field Research Survey 2019).

Question 2: In your own perspective, what have been the impacts of Nigeria's land borders closure on border communities, national/regional economies and security?

\begin{tabular}{|l|l|l|l|}
\hline Serial No. & Response & Frequency & Percentage \% \\
\hline 1. & Yes & 296 & 74.17 \\
\hline 2. & No & 100 & 25.13 \\
& Total & 396 & $100 \%$ \\
\hline
\end{tabular}

Source: Field Research Survey, 2019.

Respondents' responses on the various impacts of the closure on border communities, economy and security

\section{Impacts on Border Communities}

- Since the Nigerian government shut all the land borders in August, 2019, a large number of financial experts and economists have faulted the government's claims that the gains 
of border closure are only seemed to be negative effects on the nation's economy and as well the untold hardship the situation had brought upon the legitimate importers and people living in border communities (Field Research Survey, 2019).

- Some of the respondents indicated that some of the manufacturing companies in the country, for example; Cadbury Plc, Dangote Group, among several others lost over N1.29 trillion as a result of the Nigerian borders closure policy in over a year ago while over 2,200 trucks laden with varieties of goods and raw materials got trapped and rotted away at the border areas. At the initial stage, the owners of the goods and raw materials including the manufacturers were hopeful the borders would get opened shortly but eventually, their hope got dashed and made huge losses as the borders remain closed to date (Field Research Survey, 2019).

- In an interview granted with one Mr. Chabba Adewale Poroye, a motor vehicle dealer in one of the border communities lamented the loss made and his colleagues in the business groaned seriously in the first five (5) months of the closure but they later put themselves by finding alternative means of feeding their families. Information also gathered from another respondent, Mr. Fanu who happened to be the Chairman, Association of Nigerian Licensed Customs Agents (ANCLA), Seme border chapter, indicated that since the closure, things turned out to be very challenging for all the clearing agents across the borders, to the extent that some of their members were lost to the hardship and cold hands of frustration - this ravaging difficult situation eventually forced most of them relocating to the Lagos ports to engage in little business to feed their families (Field Research Survey, 2019).

- In the same vein, the study explicitly reveals that Nigeria's borders closure has rendered over three million people jobless pursuant to the fact that the Customs brokerage businesses at borders remain their only "lively industry" nearly in all the border communities. It was indicated by the study that many residents in border communities thereafter eventually resorted to using their vehicles to ferry petroleum products (fuel) across the border to other locations in order to make a living and feed themselves during the closure. And during the COVID-19 pandemic, their woes became more worsened with a national lockdown, as a large number of clearing agents in the communities turned beggars with thousands of them unable to feed themselves and their family members (Field Research Survey, 2019).

- Responses from the respondents in border communities and other neighbouring states indicated that the security operatives manning the land borders and waterways were made to conspire by collecting bribes to allow illegal passage of goods and services. This indicated that an illegal avenue was "established" for people doing all sorts of illegal export trades. The security operatives manning the borders were even frustrated having not seen their families for a long time during the lockdown, hence the need to send more monies to their families - they ventured into bribes-taking. Therefore, the various shady businesses the Nigerian government wanted to prevent in the first instance that made them to take the border closure policy, got highly increased indiscriminately (Field Research Survey, 2019). 
- By the way, the various commercial banks at the border communities were not spared as their managements and officials also groaned and lamented the restrained impacts of the border closure on their business which absolutely brought down their transactions significantly. The colossal drop in volume of their business transactions also led to retrenchments of many bank officials or members of staff respectively; the drop in business was ascribed or attributed to the closure of borders for over a year to date. This situation did not exclude the various commercial bus drivers, bike riders, and cart pushers, as well as others in the border communities (Field Research Survey, 2019).

\section{Impacts on Both National and Regional Economies}

Findings from the research indicate the since the Nigerian government shut all the land borders in August, 2019, there have been combinations of both considerable improvement and strains in the nation's revenue generated respectively.

- In the first instance, the larger percentage of members of the Manufacturers Association of Nigeria (MAN) indicates the continued border closure is counterproductive to the nation's economy in the sense that numerous Nigerian manufacturers exporting goods through the land borders, if care is not taken or borders open in time, may definitely lose their market share in the West African subregion.

- $\quad$ The study reveals that majority of the Small and Medium Enterprises (SMEs) initially existing at border areas got shut down, and relocated to Lagos or other neighboring states for survival; this was pursuant to the verity that it actually became a painful setback for border users, residents in border communities and major stakeholders doing businesses over there. The situation was pathetic at Idiroko border area as the respondents regretted that the continual closure of the border created an avenue for some set of people to be rich at the expense of poor Nigerians; this as a result of the opportunity they have with a connivance with some corrupt security officers, thereby enabling smugglers find avenues to make money (Field Research Survey, 2019).

- $\quad$ The study, in its findings (88.2\% of respondents), indicate there is absolute increase in government revenue collected through custom duties. This fact is buttressed with the outcomes of the monthly Federation Account Allocation Committee (FAAC) meetings and the Nigeria Customs Service's reports from September, 2019 to date where the Minister of Finance indicates that the Nigerian Customs Service (NSC) used to generate an average of between 4.7 billion and 5.8 billion in daily revenue since the border was closed; and this is a bit improved than what was obtainable penultimate the policy pronouncement. In addition, the federal government of Nigeria, in dire need to drive more funds, increased VAT and implemented the stamp duty on all POS payments that are above N10,000 among others (Field Research Survey, 2019).

- In one of the respondents' response, a commercial bike (okada) rider in Jibia border community Orion Akpapava, it was made known that the border closure really made 
living difficult for him and his family members. The respondent revealed that even before the border closure, he used to make up to N12,000 or more on daily basis by conveying various goods and other commodities for traders with his motorcycle; and at present he hardly realize N800 daily. The various traders and other people that visit the borders to purchase goods or commodities ceased from coming (Field Research Survey, 2019).

- Responses indicate that the policy puts the economy of the border communities and other neighbouring countries in a doldrum. This remains the fact as espoused that in a saner climate, it is standard for border communities and other neighbouring countries to depend on trade, economic and business activities within and across borders to make a living but opposite has remained the case. Moreover, the variety of goods and communities also should also serve as solid economic bases for legitimate economic activities of a country and other neighbouring nations to survive or thrive. Nigeria's announcement on closing its borders to prevent movement of all goods has been met with harsh criticisms from neighbouring states and regional integration advocates in all sense (Field Research Survey, 2019).

- $\quad$ The study in its findings (78\% of the respondents) indicates that criminal activities received a boom as a result of the border closure policy of the Nigerian government. Moreover, studies reveal that international border markets are always located in these border communities where trades in goods and services from other neighbouring states are easily carried out but opposite remains the case. And normally, as the mentioned economic engagements thrive among the nations, gains of tariff collections become easily promoted; and smuggling activities get reduced to barest minimum as residents or people in the areas become gainfully employed. And as soon as people in the areas are fully engaged, they become less prone to criminal or violent activities in all ramifications (Field Research Survey, 2019).

- $\quad$ Findings also shows that since the Nigerian government shut all its land borders to other nations in 2019 with hope of checkmating the smuggling of goods into the state from neighbouring nations as well as affirming compliance with existing trade procedures and rules, the volume of intra-African trade or commerce still remains low and a large amount of the trade by nations in the continent is carried out with states outside Africa. In the same vein, the United Nations Conference on Trade and Development (UNCTAD) periodicals on Economic Development in Africa (2019), indicates that intra-Africa commerce is about $17 \%$ of total Africa exports in the years penultimate 2019 which remains very low when compared to the $59.4 \%$ and $67.98 \%$ in the continents of Asia and Europe. Though the statistic is a bit criticized to be slightly deficient pursuant to the fact that it fails to grab the volume of informal trade that takes place amongst the nations in Africa as well the amount of smuggling activities that have remained on the increase via the numerous porous land borders (Field Research Survey, 2019).

- $\quad$ Fifty six point eight percent (56.8\%) of the research responses showed a major disadvantage on negative effect it has on informal trades taking place across the land 
borders; this is as the trades and economies in the neighbouring countries suffered innumerable losses and setbacks during the period of border closure. As clearly stated, Republic Benin, one of the nations sharing borders with Nigeria is revealed to be populated with about 12 million people and drawn from a commerce viewpoint, records from the Thailand Rice Export Association (TREA) indicates that the country remains the largest Thai rice importer. And it is obvious that Republic of Benin does not possess the capacity to consume the quantity of rice she imports, meaning that the imports are repackaged and exported to the nations around it like; Nigeria that has a population of over 200 million, Togo with a population of over 8.2 million, and Burkina Faso with a population of over 20.11 million as at 2018 (World Bank Reports, 2019). Therefore with this current policy of border closure, Benin Republic has suffered a major blow to her economic drive, having lost revenue that are supposed to have been generated if a large quantities of rice are allowed to be sold to Nigeria endowed with over 200miliion population (Field Research Survey, 2019).

- $\quad$ Findings (22.1 percent) also indicates that the borders closure policy helps local production by making local goods relatively available and cheaper comparable in price with other imported goods and commodities coming into Nigeria as the importers pay the applicable tariffs on the goods, hence the need to increase the price simultaneously. The policy has also endeavoured to reduce the volume of goods which find their way into Nigeria thereby providing liberal opportunities for local producers to sell their commodities to local consumers without unhindered (Field Research Survey, 2019).

- $\quad$ The study also shows that the policy of land borders closure has instigated an increase in the prices of staple foods in the country, most especially rice which has remained one of the famous or highly-consumed foods in Nigeria. A bag of imported rice now sells between $\mathrm{N} 35,000$ and $\mathrm{N} 42,000$ while locally-produced rice sells for N28,000 and N32,000 respectively. In the same vein, Republics of Benin, Togo and Chad's import taxation has revolved around maximizing the income by taxing goods when they arrive the country at a rate well below the ones in Nigeria or other countries. Without mincing words, the above-mentioned countries' revenues are hard hit as a result of borders closure and recession period in Nigeria due to the very low demands for products being traded in the countries (Field Research Survey, 2019).

\section{Impacts on National Security}

The policy of borders closure has impacted on national security in these ways:

- The central question on the national discourse is what exactly this land borders closure policy aims to achieve; and government claims it would help curb smuggling of goods through its land borders thereby strengthening domestic or local production and therefore improve national productivity at all levels. These objectives of the Nigerian government in particular, in some way imply the ineffectiveness of its customs and immigrations service especially with the inability of the state to adequately protect its borders and effectively enforce import restrictions on certain commodities. But from the look of 
things, it is observed that the border policy has not been able to achieve its end-goal in the short-term or in the long-term due to the structural problems that thrive in the country in all ramifications (Field Research Survey, 2019).

- In the same way, police checkpoints increased in numbers and the operatives usually got themselves strategically stationed at the outer parts of the borders, while residents made use of their commercial vehicles and bikes to siphon fuel in kegs and resold to the people across the border areas at night making their ways via bush parts and porous borders being created on daily basis, to make a living (Field Research Survey, 2019).

- The study found out that there are over 1,420 illegal border routes across Nigeria, meaning that there exist numerous routes where petroleum (fuel) is be smuggled out of the country to others states. Besides, there is poor security around the borders and the high level of corruption amongst the security operatives, most especially the immigrations and customs services (Field Research Survey, 2019).

- A large of response indicates that the Nigerian government is highly corrupt and deceiving the entire country people. The submission is attributed to the fact that despite announcement that all land borders remained shut as by the Nigerian government, a large percentage of respondents (64\%) exposed that smuggling of foreign rice and edibles like vegetable oil, frozen chickens among others were still on the increase. Respondents emphasized that the banned commodities were still found everywhere in the markets, the foreign rice smuggled into the country illegally were easily re-packaged and made to look like local products. This submission attests to the fact that there is high rate of corruption in the country and the current government is only deceiving the general public that it is waging war against the menace. The smugglers engaged the service of the corrupt security operatives to lead their entourage having been massively bribed (Field Research Survey, 2019).

- In the main time, the policy of border closure has been very disadvantageous to the people in Nigeria; this is due to the fact that the government cannot continue to make the citizens pay or suffer for its inefficiencies at all times. Therefore, it is a statutory responsibility of the government to secure, protect and safeguard the land borders but government's inability to effectively do this has posed heinous threats to the citizenry's human security in all ramifications - as a result of government's failure to provide them with any tangible palliative or prior information to prepare them adequately for the policy of land borders closure (Field Research Survey, 2019).

- The study in its findings reveals that since the policy of border closure was launched and implemented, the residents in border communities who used to be dependent on border trades and activities for survival are now living in abject poverty, leaving numerous with no choice than to indulge in all sorts of illegal businesses at the borders. The research exposes that Nigeria state shares international land borders with Chad, Cameroon, Benin Republic, and Niger, and lots of border communities which include: Ilaro, Idiroko, Seme, 
Oke Odan, Ipokia, Owode, Mawun, Alari, Koko, Badagry, Ajilete, Ago, Ighonyedo and Ifo, Okerete, Banki, Maitagari, Imade Dura and Jibia among others. The residents have from the time immemorial depended on border commercial activities: transportation business, clearing and forward agency, and as well as currency exchange trades for survival (Field Research Survey, 2019).

\section{Limitations to the Study}

The researcher though initially decided and planned to visit all the various selected border communities which include: Ipolia, Banki, Ilaro, Idiroko, Okerete, Seme, Oke Odan, Owode, Mawun, Alari, Koko, Badagry, Ajilete, Ago, Jibia, Ighonyedo and Ifo, Maitagari, Imade and Dura, to gather adequate data for the study but was only fortunate to visit four (4) border communities of; Badagry, Banki, Idiroko, and Seme respectively due to increased insecurity that had taken different dimensions in the country. Copies of questionnaire were distributed to some security personnel (Nigeria Immigration and Customs Services) at Nigeria's borders and other neighbouring states while a date and appointment were fixed for interviews with selected respondent officials. But unfortunately on the fixed or appointed date, the researcher was disappointed as the personnel already selected and approved to grant the interviews were not found on duty. Moreover, the researcher was able to retrieve only just the one-third (1/3) of copies of the questionnaire earlier distributed to respondents due unavailability of most of the personnel and fear of insecurity in the areas - all these remain the bottlenecks for the study.

\section{Recommendations}

Strategizing on how to curtail the menace of smuggling at borders, insecurity, and all illegal and criminal activities towards ensuring perfect border security in Nigeria, recommendations are offered as follows:

- $\quad$ There is need for cross-fertilization of ideas and strategies between Nigeria and others states in Africa on how to fight illicit activities and undocumented migration through her borders. There is need for adopting an interdiction process which means a strategic effort of disrupting all illegal movements across all Nigerian borders.

- In order to effectively curb of smuggling and strengthen the local and domestic capacity for national productivity at all levels, there is need for a multi-faceted approach from Nigerian government: to improve the capacities of its customs and immigration services, improve access to micro and macro-credit for farmers and entrepreneurs, execute land mapping and reforms, motivate private sector investments, and promote ease of access to stable and affordable electricity supply as well as incentivize private sector investments.

- Though it is observed that Nigeria remains a prominent campaigner of sharing a common external tariff and currency and among itself and other neighbouring states but this effort might not be the best strategy towards enhancing the West African integration agenda. It is recommended that the country should take some courageous steps towards diversifying her economy instead of her usual dependence on border closures all the time. 
- In the same vein, Nigeria's agencies; customs, immigrations, police and other security agencies meant to control and protect the borders henceforth should be more and adequately equipped with surveillance equipment, bomb and metal detectors, screening machines, unmanned aerial vehicles (UAVs) or drones, sniffer dogs, and human intelligence among others to curtail or checkmate smuggling and other transborder crimes.

- It is also recommended that there should be instant formation of buffer zones within the Nigerian borderlands as secondary checkpoints on all the vehicles and people who have already crossed the main borders, as these would further secure the borders from all sorts of illegal and criminal activities.

- $\quad$ Besides, a multinational task force of security operatives from Nigeria and its neighbouring states should be adequately put in place for a joint patrol of borders. In addition to this, the Nigerian security agencies should unavoidably exploit a networked security intelligence contributing to and using shared intelligence information across national boundaries. Also, the Nigerian government should strive to encourage or put in place some local security formations: the civilian joint task force, and vigilante groups who are the locals and endowed with adequate security knowledge of their terrain to assist in border security and control.

- In the same vein, the various agencies or institutions that are in charge of population management and national identity should carry out a thorough verification of the nation's population in the next census to know those who are truly foreigners, illegal ones and the process in which they find themselves into the country. And there is a need for Nigerian government to build some low cost houses for workers, invest substantially in its education sector, health and develop rural communities. While focusing and obsessed with the trite problems with our neighbours, we should also tackle the huge challenges facing the country based on the above arguments.

- Lastly, all the states in the continent of Africa should without wasting time adopt the usage of comprehensive data collation systems and drone technologies on smuggling activities that would assist in tracking and sharing information on the actual trends, patterns and changing nature of smuggling routes in the region; and at the same time establishment of a database of arrested and convicted smugglers.

\section{Conclusion}

At present, most African borders are managed in such a way that easily allows illegal arms or weapons and criminals to freely move across them, and this poor border management issue has remained the major trigger of insecurity in the country and West African region respectively. At the same time, the porosity of Nigeria's borders with her neighbouring nations has actually made illegal cross-border engagements and undocumented migration possible, thereby contributing 
Journal DOI: 10.46654/IJRESD

immensely to the worsening state of economy and insecurity in the country. But it is not too late to strictly adhere to the above-mentioned recommended strategies towards enhancing the security and economies of African states at large. It is therefore indisputably believed that this research would definitely go a long way in guiding the Nigerian government as well as other neighbouring states in Africa on how to reform and reposition their borders security; populationmanagement institutions; and finally to discourage all sorts of upheavals which illegal crossborder commerce or trades, criminal activities, and undocumented migrations have posed to the various states in Africa. And it is however concluded that the border closure poses a major blow to pan-African moment and failed to incur economic and security blessings having cut short all trade relations with other states; having initially envisaged that the policy would be very significant in protecting Nigeria's political, economic and security interests. Lastly, if the land borders are not opened for business in time, many of the Nigerian manufacturers that used to export their goods through the borders could permanently forfeit their market share in the West Africa region.

\section{Acknowledgement}

I hereby appreciate the input of members of the various bodies and respondents for their tireless efforts during the work. 
Journal DOI: 10.46654/IJRESD

\section{References}

Adeyinka, A.M. (2014), Trans-border movement and trading activities across Nigeria-Benin Republic border. Mediterranean Journal of Social Sciences. Rome 5(1) Jan. 2014.

Adesina, O. (2019), Conceptualizing Borders and Borderlands in a Globalizing World. African Journal for the Psychological Study of Social Issues, AJPSSI, Vol. 22, Vol. 1

Agbota, S. (2020). Border closure and effects on border communities. The Punch newspaper.

Ahmed, M. (2020). "Continued border closure counterproductive”. Manufacturers Association of Nigeria (MAN). Retrieved on 4 December, 2020 in Punch newspaper

Basil A. A. (2019). Crimes at Nigerian borders. Vanguard newspaper; retrieved Jan. 21, 2020

Caflisch, L. (2006). Reform of the European Court of Human Rights: Protocol no. 14 and Beyond. Oxford University Press, pg. 403-415

Central Bank of Nigeria (2016), Measuring Informal Cross-Border Trade in Nigeria (Abuja: External Sector Statistics Division, Statistics Division), pp. 1-46.

Diener, K. and Hagen, P. (2012). Theorizing Borders in a Borderless World: Globalization, Territory and Identity. Geography Compass. 3, 3. Pg. 1196-1216

Economic Development in Africa Report (2019)

ECOWAS Report (1975).

Field Research Survey (2019), "Illegal Cross-Border Engagements And Undocumented Migration: Obstacles to Border Security In Nigeria"

Guo, R. (2015). Cross-border Management: Theory, method and Application. Springer Publishers, USA.

Hardi, T. and Uszkai, A. (2017). Theoretical Models of Cross-border Integration, in "Sociální studia / Social Studies", 1, pp. 9-30.

Hawley, C. (2005), "In Altar, Teeming with Transients, Small Town Shares Arizona's Conflicts over Impact of Illegal Immigration." The Arizona Republic (Phoenix) (August 21), Al, A20.

Kolossov, V. (2012), EU borders capes: State of the Debate Report I. Available at:http://www.euborderscapes.eu/fileadmin/user upload/EUBORDERSCAPES State of Debate Report 1.pdf

Miller, D. (2012), Border Regimes and Human Rights (CSSJ Working Papers Series, SJ021, September). Oxford: University of Oxford. 
Journal DOI: 10.46654/IJRESD

Minghi, J. (1963), Boundary Studies in Political Geography, in "Annals of the Association of American Geographers", p. 407.

Musa, S. (2013), How al-Qaeda, Boko Haram Smuggle arms into Nigeria. Vanguard, 2013, May 11.

National Bureau of Statistics Report (2019).

Newman, D. (2011), Contemporary Research Agendas in Border Studies: An Overview. In D. Wastl-Walter (ed.) The Ashgate Research Companion to Border Studies. Farnham: Ashgate.

Newman, D. and Paasi, A. (1998). Fences and Neighbours in the Postmodern World: Boundary Narrative in Political Geography. Journal of Progress in Human Geography, 22(2): 186207

News Agency of Nigeria, 2015

O'Dowd, L. (2003). The Changing Significance of European Borders. In L. O'Dowd, j. Anderson, and T. Wilson (Eds.), New Borders for a New Europe. Taylor and Francis, pg. 13-36

Odunsi, W. (2014). Illegal Nigeria immigrants caught with Nigerian voters' cards. Daily Post

Oguntoye, P. (2020). Implications of border closure on Nigerian economy. The Punch newspaper, retrieved via www.punchng.com on March 20, 2020.

Prabhakar, P. (2010), Hegemonic Stability Theory and the 20th Century International Economy, in "E-International Relations", pp. 1-7.

Ramutsindela, M. (2014), Instead of Re-Drawing the Map, Let's Transform Our Borders. Available at: https://psmag.com/news/instead-re-drawing-map-lets-transform-borders$\underline{96940}$

Simon, H. A. (1997). The Concept of Rationality: Boundaries and procedures. Brazilian Journal of Political Economy. Sao Paulo. Vol. 30, No. 3

United Nations (2008) 'Drug Trafficking As a Security Threat in West Africa,' the United Nations Office on Drugs and Crime, November 2008 U.S. Department of Justice (2013). "Ungoverned Spaces, Transnational Crime, and the Prohibition on Extraterritorial Enforcement Jurisdiction in International Law"06-11.

Vaughan-Williams, N. (2009). Lines in the Sand? Towards an Agenda for Critical Border Studies. Journal of Geopolitics, Taylor and Francis. Vol. 14, Issue 3.

Weber, A. (2012), Boundaries with Issues: Soft Border Management as a Solution? Available at: http://library.fes.de/pdf-files/iez/08869.pdf

World Bank Reports (2019). 
International Journal of Research in Education and Sustainable Development | ISSN: 2782-7666

Journal DOI: 10.46654/IJRESD

Vol. 1, Issue 1 (January, 2021) | www.ijaar.org

Article DOI: 10.46654/IJRESD.117125

Zartman, W. I. (2010), Identity, Movement and Response. In W. I. Zartman (ed.) Understanding Life in the Borderlands: Boundaries in Depth and in Motion. Athens, GA: University of Georgia Press. 